Годишьак Филозофског факултета у Новом Саду, Кьига ХХХІХ-2 (2014)

Annual Review of the Faculty of Philosophy, Novi Sad, Volume XXXIX-2 (2014)

Aleksandra Blatešić

Filozofski fakultet Univerziteta u Novom Sadu

UDK 811.131.1'367.3

Originalan naučni rad

\title{
NULTA IMENIČKA SINTAGMA U ELIPTIČNIM STRUKTURAMA ITALIJANSKOG JEZIKA ${ }^{1 *}$
}

Osnovnu temu ovog istraživačkog rada čini nulta imenička sintagma, koja se u italijanskom jeziku često pojavljuje u redukovanim sintaksičkim strukturama. Do izostavljanja sintaksički redundantnih jedinica iskaza dolazi iz nekoliko razloga, među kojima su za ovaj predmet istraživanja najbitniji ekonomija jezika, emfaza i stil. Pojava nulte imeničke sintagme u italijanskom jeziku vrlo često koincidira sa elipsom, te smo posebnu pažnju obratili na vrstu elipse u kojoj se pojavljuje nulta imenička sintagma (retorička i gramatička), ali i na vrstu glagola koji se izostavlja u eliptičnoj strukturi. Ove redukovane strukture istražili smo na površinskom i dubinskom nivou iskaza, oslanjajući se na principe generativne gramatike i savremenog strukturalnog metoda. Rezultati istraživanja predstavljaju sintaksičko-semantičke uslove i jezičke kontekste koji dovode do pojave SNØ u elipsi. elipsa

Ključne reči: italijanski jezik, imenička sintagma, nulti član, gramatička elipsa, retorička

\section{UVOD}

Elipsa (od grč. élleipsis ,,nedostatak“) je rečenica u kojoj je, iz razloga ekonomičnosti, emfaze ili stila, jedan deo strukture izostavljen, a može se rekonstruisati na osnovu ispitivanja konteksta (Kristal, 1985: 87). Tradicionalna lingvistika pravi razliku između gramatičke i retoričke elipse, te italijanski lingvista Korno podseća da se praznine gramatičke elipse (,in praesentia“) mogu ispuniti elementima iskaza koji su predviđeni gramatičkom strukturom ili modelom, dok je za retoričku elipsu (,in absentia“) neophodno poznavanje referencijalnog okvira iskaza koji se može dopuniti parafrazom (Corno, 2010). Tako slušalac ili čitalac može dopuniti sadržaj elipse „in praesentia“ već na osnovu datog jezičkog materijala, ali mu je za dopunu praznine u elipsi ,in absentia“ neophodno poznavanja šireg konteksta.

Ova distinkcija je poznata još od antičkog doba, te u delu Institutio oratoria Kvintilijan ističe potrebu za razlikovanjem elipse od aposiopeze, vrste mikrostrukturalne retoričke figure. Naime, u slučaju elipse izostavljaju se reči ili oni delovi diskursa koji se mogu svesti na preostale reči u iskazu bez gubljenja značenja

\footnotetext{
*ablatesic@yahoo.it

Ovaj rad predstavlja proširenje osnovne teme obrađene u doktorskoj disertaciji „Nulti član u savremenom italijanskom jeziku“, odbranjene na Filološkom fakultetu u Beogradu, 30. marta 2012. godine.
} 
(Pennacini, 2001: 58), dok je kod aposiopeze neophodno iskoristiti drugu kombinaciju reči kako bi se protumačilo ono što je izostavljeno u tekstu ili govoru (Pennacini, 2001: 60). U aposiopezi (gr. ỏđd’óé-ţđçóéň, muk, ćutnja) se upravo prećutkivanjem ističe ono što nije izrečeno tako što govornik prekida iskaz u trenutku kada treba dovršiti rečenicu i izreći glavnu misao, ostavljajući slušaocu da je nasluti na osnovu konteksta (Bagić, 2010: 9).

U srednjem veku učitelji retorike su preporučivali elipsu kao sredstvo za postizanje veće konciznosti govora, a još u Danteovoj „Commedia Divina“ zapažamo veoma čestu upotrebu gramatičke elipse, kao što je ispuštanje glagola dire u dijalozima (e io a lui, ed elli a me, questo io a lui), te ispuštanje prideva ili zamenica (Tateo, 1970). U svim tim upotrebama elipsa služi kao osnovno sredstvo za sažimanje teksta ili diskursa.

Početkom XIX veka Pjer Fontanije, jedan od prvih lingvista koji se poduhvatio sistematizovanja i pravilnog definisanja retoričkih figura u nekoj obimnijoj studiji $^{2}$, svrstava elipsu među figure „reči“, a ne „mišljenja“, čime pridaje veći značaj redu reči u odnosu na njihovo značenje (Corno, 2010). Fontanije, međutim, zapaža upotrebu elipse kao modela međurečeničnog povezivanja u dijalozima, naročito u varijantama ,pitanje-odgovor“, o čemu će biti govora i u ovom radu.

Počev od XIX veka pojava elipse se sve više vezuje za nominalni stil, te je poznata pod nazivom ,elipsa predikata“. Zapažamo je već u radovima italijanskog pisca Alesandra Manconija ${ }^{3}$ (Mancini, 2007: 708), dok se čisto nizanje informacija u asindetskoj strukturi kao retorički fenomen pojavljuje kod pesnika Euđenija Montalea $^{4}$, kao i u italijanskoj poeziji druge polovine XX veka (Corno, 2010). U savremenom italijanskom jeziku elipsa predikata je u najvećoj meri prisutna $\mathrm{u}$ naslovima svih vrsta publikacija (dnevna štampa, knjige, reklame, itd.).

Elipse predikata koje pronalazimo u jeziku XX i XXI veka nisu zasnovane samo na mehanizmu skraćivanja govora ili teksta, već zahtevaju i direktnije učešće primaoca poruke radi njenog tumačenja. U kompleksnoj strukturi ovakvih elipsi sadržane su kako elipse „,in praesentia“ tako i one „in absentia“, a tumačenje iskaza u velikoj meri zavisi od situacionog konteksta i saznajne kompetencije primaoca poruke. U raznim vrstama diskursa i teksta primenjuje se princip ekonomije jezika koji nalaže brisanje svih redundantnih sintaksičkih ili leksičkih elemenata. Devedesetih godina XX veka nastale su mnoge studije govornog jezika, koje ukazuju na visoku prisutnost nominalnih struktura, a u italijanskom jeziku te strukture čine čak jednu trećinu ukupnih iskaza (Cresti, 1998: 171-172, Cresti, 2005: 6-7).

U ovom radu istražićemo uslove koji utiču na pojavu imeničke sintagme bez člana (SNØ) u eliptičnim strukturama ,in praesentia“ i ,in absentia“, i to koristeći se principima generativne gramatike i strukturalnog metoda. Posmatraćemo

$2 \quad$ Reč je o delu Des Figures du discours autres que les tropes iz 1827. godine, koje se koristilo kao osnova za nastavu retorike u Francuskoj u XIX veku.

3 Mančini ističe da je Manconijeva sklonost ka nominalnom stilu preko upotrebe elipse zapažena još u njegovom kapitalnom delu Promessi sposi (Mancini, M., Scrittura del tumulto e tumulto della scrittura. Aspetti metanarrativi e metalinguistici in Promessi sposi XI-XVI. In: Italica, Winter, Vol. 84, No. 4, pag. 708).

$4 \quad$ U zbirkama pesama Ossi di seppia i Le Occasioni. 
pojavu determinisane (SNdet), nedeterminisane (SNindet) i nulte imeničke sintagme (SNØ) u površinskoj i dubinskoj strukturi iskaza, grupisanih prema vrsti izostavljenog glagola u elipsi (glagol punog značenja, glagol esserci u egzistencijalnim rečenicama, kopulativni i semikopulativni glagol). Za korpus ove istraživačke teme odabrali smo književna dela italijanskih pisaca XX i XXI veka ${ }^{5}$, te smo time u centar istraživanja postavili savremeni italijanski jezik. Autore odabranih književnih dela odlikuje različit stil pisanja što je takođe bilo važno prilikom obrade ove teme. Tako delo Umberta Eka obiluje primerima starijih struktura italijanskog jezika, dok kod Alesandra Barika i Nikole Amanitija nailazimo na učestale dijaloške replike, skraćen ili isprekidan govor i kolokvijalan jezik. Čekovinijevo delo nam, sa druge strane, omogućuje uvid u primere metajezičke upotrebe, kao i veoma frekventne eliptične strukture usled isprekidanog narativnog stila. Delo Enca Bjađija je izabrano radi novinarskog stila pisanja, za koji je karakteristična upotreba nulte imeničke sintagme.

Na osnovu uvida u literaturu sa temom nulte imeničke sintagme zaključili smo da nedostaje temeljnija obrada ove pojave u eliptičnim strukturama. U obimnijim deskriptivnim gramatikama italijanskog jezika ${ }^{6}$ i u naučnoj literaturi koju smo koristili u ovom radu elipsa je zapažena kao struktura pogodna za izostavljanje člana, ali sintaksičko-semantički uslovi koji dovode do upotrebe nulte imeničke sintagme nisu dovoljno obrađeni. Stoga je cilj ovog rada da predstavi eliptične strukture u kojima se koristi imenička sintagma bez člana, razlike između tih struktura, kao i eventualna pravila koja doprinose korišćenju SNØ u elipsi.

\section{SNØ U ELIPSI NASTALOJ IZOSTAVLJANJEM PREDIKATA PUNOG ZNAČENJA}

U ovom odeljku predstavićemo primere SNØ u elipsi, nastaloj izostavljanjem predikata punog značenja, shvaćenog kao suvišnog elementa za razumevanje sadržaja poruke. Imeničke sintagme ćemo podeliti u dve grupe, one koje u iskazu vrše funkciju subjekta i one koje služe kao objekti.

\subsection{SN u subjekatskoj funkciji}

Ove imeničke sintagme su uglavnom determinisane, a odnose se na pojmove poznate iz konteksta ili na pojmove čija se dodatna identifikacija traži u dijaloškim replikama (chi - ko, quale - koji, itd.). Mogu se javiti u vidu imeničke sintagme sa određenim (1), (2), (3) ili neodređenim članom (4). Nulte imeničke sintagme (SNØ) se retko pojavljuju, i to uglavnom u množini ${ }^{7}$, koja ima značenje neodređene

\footnotetext{
Na kraju rada dat je spisak književnih dela iz korpusa, kao i njihovih skraćenica.

6 Za potrebe ovog rada konsultovali smo dve opširne gramatike savremenog italijanskog jezika: Grammatica italiana con nozioni di linguistica (M. Dardano, P. Trifone, Bologna Zanichelli Editore, 1995) i Grammatica italiana (L. Serianni, Torino, UTET Libreria, 2005).

7 O uticaju gramatičke kategorije broja na pojavu nulte imeničke bilo je reči u brojnim diskusijama i radovima drugih istraživača ove teme (Contreras 1986, Casalegno 1987, Zamparelli 2002, Dayal 2004).
} 
količine (5). Pojava nulte imeničke sintagme u jednini moguća je u nizovima u okviru teksta, koji se nadovezuju na prethodni iskaz sa glagolom i SNindet (6). U navedenim primerima imeničke sintagme su istaknute kurzivom, dok su glagoli, sa kojima su semantički povezane u diskursu ili tekstu, podvučeni linijom.

1) - Lo sai, me lo avevano detto che tornavi.

- Chi?

- Gli orsetti lavatori. (NHP, str. 116)

2) Venivano verso di noi. I signori della collina. (NHP, str. 218)

3) - Senti che roba ... -, disse a un certo punto, inspirando deliziato l'aria della sera.

- Quale roba? -, chiese il Tarin.

- L'odore di letame -, chiarì Libero Parri, tornando a inspirare teatralmente. (QS, str. 31)

4) - Chi è̀? Chi è̀? - ho balbettato ...

Un rospo! (NHP, str. 203).

5) In un altro angolo erano ammassati dei mobili. Una vecchia cucina rovesciata e arrugginita. Bottiglie. Cocci. Tegole. Una rete sfondata. (NHP, str. 27).

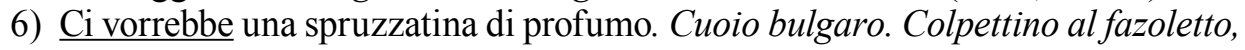
specchio, passo indietro. (SIP, str. 40)

\subsection{SN u objekatskoj funkciji}

$\mathrm{Na}$ osnovu primera pronađenih u korpusu, kao i na osnovu jezičkog konteksta u kojima se javljaju ispitivane SNØ primetili smo da nulte imeničke sintagme najčešće vrše funkciju objekta (7), (9), (10), a nekada i objektoida (8):

7) - Cosa ci vedi?

- Tentativi, dice.

- Tentativi di cosa? (QS, str. 151)

8) [...] Ascolti me, da quelle parti hanno bisogno di altro.

- Mucche? -, aveva azzardato, pessimista, Libero Parri.

- No. Camion.

Automobili per lavorare, gli aveva spiegato. Autocarri, macchine per lavorare la terra, furgoncini. (QS, str. 54)

9) - Come? Non ho capito.

- Acqua.

- Acqua? Hai sete? (NHP, str. 65)

10) Con tutt'altra freddezza e gioia, urlava, sorprendentemente, il proprio nome, a squarciagola. Nome e cognome, per l'esattezza. (QS, str. 38).

Iako je upotreba SNØ u objekatskom položaju frekventnija u množini (7), (8), primer (9) pokazuje da SN u jednini može biti SNØ ukoliko je reč o zbirnoj ili 
gradivnoj imenici. Tako je SNØ u replici “Acqua." realizovana u okviru jedne jedine reči, ali ima značenje cele rečenice (Voglio acqua./Voglio bere acqua.), koje spoznajemo na osnovu uvida u situacioni kontekst ${ }^{8}$. Pojava drugih vrsta imenica, a ne samo zbirnih u obliku SNØ (Sg.) nije isključena, ali su to onda rečenice u kojima je izostavljen predikat na koji se odnosi SNØ (9), a ne SNØ koja se nadovezuje na izražen predikat u prethodnoj replici $(7,8,10)$. Između ovih primera postoji razlika u vrsti elipse: primer (9) predstavlja elipsu "in absentia", dok su u primerima (7), (8) i (10) prikazane elipse "in praesentia", i to u okviru modela međurečeničnog povezivanja u dijalozima tipa 'pitanje-odgovor'.

Elipsa može da nastane i kao rezultat skraćivanja idioma, kolokacija ili kontekstualno logičkih struktura koje su frekventne i uobičajene u svakodnevnom govoru. Takve elipse su mahom retoričke, često se koriste i u književnim delima, kako u dijalozima tako i u naraciji, a doprinose isticanju upotrebljene nominalne strukture. Imeničke sintagme koje se pojavljuju u takvim elipsama su bez člana, a rekonstrukcijom jezičkog konteksta otkrivamo da je reč o SN koje u dubinskoj strukturi imaju funkciju objekta, inače pogodnog položaja za pojavu SNØ, što su uočili i mnogi drugi istraživači ove teme.

Tako Paola Beninka smatra da se objekatska SNØ u jednini pojavljuje usled prisustva fonetski nerealizovanog kvantifikatora, dok se nulta imenička sintagma u množini pojavljuje usled prisustva kvantifikatora neodređenog broja, bez autonomne fonetske realizacije (Benincà 1980: 53). Longobardi, koji je takođe uočio da su SNØ u objekatskom položaju dominantnije, nalazi objašnjenje u tome da je to položaj sa leksičkim upravljanjem (1994: 614-625). Najdetaljniji prikaz ove pojave dao je Korzen, koji zaključuje da se objekatska SNØ u jednini pojavljuje u sklopu glagolske sintagme, kao imenički deo predikata ili iza "glagola podrške“ (verbi supporto), koji se odlikuju slabom semantičkom vrednošću (Korzen 1996: 147). Potpuno značenje ovih glagola zavisi od imeničkog konstituenta, jer nisu sami po sebi denotativni (avere, essere, fare, dare, prendere, mettere, venire itd.) (Korzen 1996: 87). Iako primeri iz našeg korpusa potvrđuju ovu tezu o povezanosti objekatske SNØ i određene grupe glagola, razlike između dubinske i površinske strukture navedenih primera navode nas da produbimo Korzenov zaključak.

(11) Non mangerà. Pazienza. (NHP, str. 69)

Pazienza. $\leftarrow$ Abbi pazienza.

(12) Il figlio era una peste, mi piaceva da pazzi. Capelli rossi, lentiggini. (QS, str. 177)

Capelli rossi, lentiggini. $\leftarrow$ Aveva capelli rossi e lentiggini.

(13) Esempio storico: $\leftarrow$ Guicciardini, per difendere il suo "particulare", resta al servizio dei papi che odia. (GDM, str. 177)

Esempio storico. Facciamo un esempio storico.

8 Rečenicu „Acqua.“ izgovara dečak u zatočeništvu, pronađen u vrlo lošem fizičkom stanju. Na osnovu ovakvog konteksta jasno je da se navedeni iskaz odnosi na zahtev za vodom. 
Tako još u dubinskoj strukturi primera (11) i (12) primećujemo da se objekatske imeničke sintagme javljaju bez člana, što znači da do formiranja SNØ u površinskoj strukturi nije došlo samo usled izostavljanja glagola podrške, već da je to rezultat nekog drugog procesa. Naime, glagolske strukture koje se oslanjaju na SNØ bile su više rasprostranjene u prvim fazama razvoja italijanskog jezika (Blatešić 2012: 48-50, 138-139, 451). Danas se mnoge takve imeničke sintagme nalaze na granici kategorije idioma i frazeologizama, koji teže uspostavljanju ustaljenih struktura kako bi se razlikovali od slobodnih izraza. Stoga, usled vanjezičkih uticaja dolazi do favorizovanja sintaksički restriktivnih i semantički selektivnih struktura, dok tip bez determinante $u$ modernom italijanskom poprima minoran značaj i prizvuk konzervativnog.

Zanimljivo je i objašnjenje italijanskog lingviste Marinija (Marini: 2000: 264), koji smatra da upravo odsustvo determinante daje prostora za parafraziranje, $i$ to uz upotrebu glagola koji najbliže odgovara glagolu u datoj strukturi. Ovo objašnjenje ipak pokriva manji broj primera.

(14) Luca ha rapidamente menzionato i fatti accaduti.

Luca ha fatto rapidamente menzione dei fatti accaduti. (Marini, 2000: 264).

\section{SN U ELIPSI NASTALOJ IZOSTAVLJANJEM KOPULATIVNOG I SEMIKOPULATIVNOG GLAGOLA}

U ovom odeljku prikazaćemo pojavu nultog člana u SN u eliptičnim rečenicama koje u svojoj dubinskoj strukturi sadrže kopulativni glagol. Prilikom poređenja površinske i dubinske strukture ovih iskaza pokušaćemo da ustanovimo da li i u kolikoj meri prisustvo / odsustvo kopule i različita distribucija imeničkih sintagmi (prekopulativna / postkopulativna) utiču na promenu determinisanosti SN.

\subsection{SN u prekopulativnoj poziciji u dubinskoj strukturi}

Ovde ćemo prikazati imeničke sintagme u jednini i množini koje zauzimaju inicijalni položaj u rečenici, kako u površinskoj tako i u dubinskoj strukturi. U površinskoj strukturi navedenih primera primećuje se da su izostavljeni kopula, koja se direktno odnosi na inicijalnu SN, kao i član date sintagme. U dubinskoj strukturi zapažamo da navedene SN poseduju determinantu, vrše funkciju subjekta i pojavljuju se sa glagolom essere. Ove promene se ne odražavaju na distribuciju ostalih rečeničnih konstituenata, tako da zaključujemo da se tiču isključivo korelacije subjekta i kopule.

(15) Italiani, brava gente. (GDM, str. 174)

$\rightarrow$ Gli italiani sono brava gente.

(16) Soldi buttati. È un ladro quello, [...]. (NHP, str. 104)

$\rightarrow$ Questi (Quei) soldi sono buttati. 
(17) Risposta esatta, ragazzo. (QS, str. 34)

$\rightarrow$ La risposta è esatta, ragazzo.

Primer (16) "Soldi buttati.“, pored toga što potvrđuje našu pretpostavku da pojava kopule zahteva postojanje determinante uz SN sa kojom je kopula u korelaciji, pokazuje i da determinanta ne mora da bude samo iz kategorije člana. Tako se u dubinskoj strukturi ovog iskaza umesto člana pojavljuje nulti demonstrativ (soldi $=$ questi $/$ quei soldi).

U poslednjem primeru (17) “Risposta esatta." zapazili smo da u površinskoj strukturi uz SNØ može da stoji i pridev, koji u tom slučaju čini deo predikata. Pridev uz SNØ može da bude i particip prezenta koji nije deo predikata, ali je nosilac relativnog odnosa, s obzirom na to da se transformiše u relativnu rečenicu. Ovakve konstrukcije su inače karakteristične za rečenice sa složenom dubinskom strukturom:

(18) Insetti svolazzanti intorno alla carogna - poco più che un fastidio. (QS, str. 75)

$\rightarrow$ Gli insetti svolazzanti intorno alla carogna erano poco più che un fastidio.

$\rightarrow$ Gli insetti che svolazzavano intorno alla carogna erano poco più che un fastidio.

\subsubsection{SNØ u poslovicama eliptične strukture}

Primere SNØ pronalazimo i u brojnim italijanskim poslovicama eliptične strukture, u kojima usled izostavljanja kopulativnog glagola, dolazi do izostavljanja člana u imeničkoj sintagmi. Na zaključak da je upravo izostavljanje kopule osnovni uzrok pojave nulte imeničke sintagme, a ne neki drugi sintaksički ili semantički aspekti navodi nas i tipološka raznovrsnost SNØ, koje se u ovim strukturama javljaju samostalno $(26,27)$, u paru $(21,25)$, sa pridevom u postnominalnoj lokaciji $(19,20,23,28)$, te sa predloškim strukturama $(22,24)$. Osnovni rečenični konstituenti ovakvih poslovica su nominalni delovi predikata, koji postaju ključni za razumevanje poruke poslovice, dok na izostavljanje kopulativnog glagola essere ukazuje samo interpunkcijski znak - zapeta. U donjim primerima predstavljamo poslovice sa elipsom i njihov oblik sa izraženim kopulativnim glagolom:

(19) Frutto proibito, più saporito.

$\rightarrow I l$ frutto proibito è più saporito.

(20) Gente accolta, gente stolta.

$\rightarrow L a$ gente accolta è gente stolta.

(21) Donna e luna, oggi serene e domani brune.

$\rightarrow L a$ donna e la luna oggi sono serene e domani brune.

(22) Figlie da maritare, fastidiose da governare.

$\rightarrow$ Le figlie da meritare sono fastidiose da governare.

(23) Febbre autunnale, o lunga o mortale.

$\rightarrow L a$ febbre autunnale è o lunga o mortale. 
(24) Lacrime di donna, fontana di malizia.

$\rightarrow$ Le lacrime di donna sono fontana di malizia.

(25) Latte e vino, veleno fino.

$\rightarrow I l$ latte e $i l$ vino sono un veleno fino.

(26) Padre, padrone.

$\rightarrow$ Il padre è padrone.

(27) Esperienza, madre di scienza.

$\rightarrow$ L'esperienza è madre di scienza.

(28) Roba trovata, mezza rubata.

$\rightarrow L a$ roba trovata è mezza rubata.

3.2. SN u postkopulativnoj poziciji u dubinskoj strukturi

I u ovoj grupi predstavićemo SNØ koje se u površinskoj strukturi javljaju u oba broja, ali koje u dubinskoj strukturi uglavnom nemaju determinantu, jer je reč o postkopulativnom položaju, koji je pogodniji za pojavu SNØ.

(29) Questione di un attimo. (QS, str. 40)

$\rightarrow$ È questione di un attimo.

(30) Colpa anche dei socialdemocratici e dei comunisti, che si sono sempre designati come partito proletario; [...] (GDM, str. 90)

$\rightarrow$ E colpa anche dei socialdemocratici e dei comunisti,...

(31) Errori di calcolo - ma la storia non è stata ancora scritta del tutto [...]. (GDM, str. 118)

$\rightarrow$ Sono errori di calcolo...

(32) Si scambiano uno sguardo. Amici per sempre. (QS, str. 17)

$\rightarrow$ Saranno amici per sempre.

Među primerima sa SNØ u predikatskom položaju možemo naći i imeničke sintagme sa pridevima koji vrše funkciju modifikatora. Iako na površinskom nivou ovi iskazi deluju istovetni prethodnoj grupi primera, predstavljenih u odeljku 3.1, u njihovim dubinskim strukturama postoji razlika. Naime, u dubinskoj strukturi rečenica sa SN i pridevom upotrebljava se član koji se potom briše kao suvišan elemenat u površinskoj strukturi. Do toga dolazi zbog pomeranja prideva na mesto determinante. Ovo naravno važi samo za imeničke sintagme sa prenominalnim pridevom (33), a ne postnominalnim koji je znatno češća struktura u italijanskom jeziku.

(33) Stessa cosa in Italia: forse i conflitti tra Nord e Sud sarebbero meno acuti. (GDM, str. 91)

$\rightarrow$ È la stessa cosa in Italia ...

Veoma je interesantna i pojava nulte imeničke sintagme sa posesivom, tj. prisvojnim pridevom u postnominalnom položaju. U italijanskom jeziku se član 
u imeničkoj sintagmi sa prisvojnim pridevom izostavlja u malom broju slučajeva, dok je uobičajeni položaj ovog posesiva prenominalni. Promenjenim položajem prisvojnog prideva postiže se emfatičnost iskaza, inače veoma čestog u govornom jeziku - Problemi suoi, Affari miei, itd. Dakle, pojava nultog člana u imeničkoj sintagmi ovakve eliptične strukture nije posledica izostavljanja kopulativnog glagola essere, već pomeranja prisvojnog prideva u postnominalnu lokaciju:

(34) „Fatti loro“, dice Lauro. (GDV, str. 81)

$\rightarrow$ Sono fatti loro.

$\rightarrow$ Sono $\boldsymbol{i}$ loro fatti.

Pojavu brisanja jedne determinante kao suvišne ne samo kod prideva, već i kod zamenica, i to u prenominalnom položaju, prikazala je Ana Kardinaleti (Cardinaletti, 2009: 133) primenjujući teoriju povezivanja, koja se oslanja na strukturalnu vezu zvanu c-upravljanje (upravljanje konstituenata). Svoju teoriju izlaže na primeru sintagme noi linguisti, koju objašnjava na dva načina:

- zamenica noi zauzima mesto determinante (D) (na kojem bi se inače nalazio član u imeničkoj sintagmi (SD) $i$ linguisti)

- zamenica noi zauzima mesto specifikatora determinisane sintagme specSD (na kojem može biti i pokazni pridev u nizu questi linguisti), dok linguisti čine upravnu reč SN.

a)

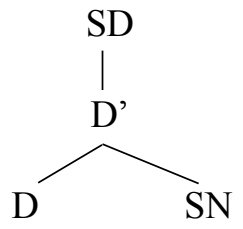

noi

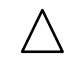

linguisti b)

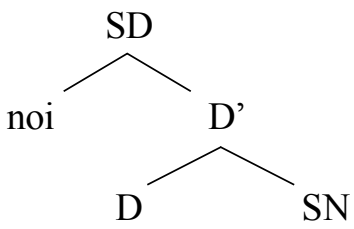

$\triangle$

linguisti

(Cardinaletti, 2009: 135)

Mišljenja smo da je bolje prvo objašnjenje ( $a$ ) iz prikaza, jer jasno ukazuje na ekonomičnu podelu uloga konstituenata iskaza i člana u funkciji determinante, koji kao suvišan element biva izostavljen, što smo uočili i u primerima iz našeg korpusa.

(35) E cosa saremmo, noi creature peccatrici, senza la paura, forse il più provvido, e affettuoso dei doni divini? (NDR, str. 478)

(36) Per questo mandano noi giornalisti a vedere. (SIP, str. 17) 


\subsection{SN u elipsi nastaloj izostavljanjem semikopulativnog glagola}

Izostavljanje semikopulativnog glagola drugačije utiče na determinisanost SN nego što je to slučaj sa kopulativnim glagolima, glagolima punog značenja i kao što ćemo videti kasnije sa egzistencijalnim esserci. Naime, SN u funkciji predikativa je sintaksički i semantički usko vezana za glagol, te se ova dva elementa pojavljuju zajedno bez stvaranja elipse. Veoma je redak slučaj da se izostavlja semikopulativni glagol, za čime se poseže uglavnom iz stilskih razloga, a u takvoj elipsi pojavljuje se SN u funkciji subjekta i to sa determinantom (SNdet):

(37) I campi sembravano fosforescenti. L'aria ferma. Le case buie, silenziose. (NHP, str. 44).

$\rightarrow$ I campi sembravano fosforescenti.

$\rightarrow$ L'aria sembrava ferma.

$\rightarrow$ Le case sembravano buie, silenziose.

Prva rečenica u ovom tekstu je jednostavne i uobičajene gramatičke strukture: 'SD + kopula + pridev'. Iako i druge dve rečenice sadrže isti glagol u dubljoj strukturi, on je izostavljen u površinskoj kako bi se izbeglo ponavljanje. U ovoj eliptičnoj strukturi imeničke sintagme su determinisane SD (l'aria, le case), jer su pridevi ferma, buie i silenziose sastavni deo semikopulativnog glagola sembrare, a ne kopulativnog glagola essere. Značenje semikopulativnog glagola iz datog primera ('činiti se', 'izgledati') ukazuje na opis predmeta, a pošto ne možemo opisivati predmete koji su nam nepoznati, zaključujemo da je ovde reč o poznatim predmetima, samim tim i determinisanim. Ovo je još jedna od brojnih potvrda da nije dovoljno uzimati u obzir samo sintaksičke elemente, već i semantičke.

\section{SNØ U ELIPSI NASTALOJ IZOSTAVLJANJEM EGZISTENCIJALNOG GLAGOLA}

Kategorija egzistencije, odnosno postojanja je kao pojmovna i semantička kategorija odavno privlačila pažnju mnogih filozofa (Aristotel ${ }^{9}$, Hajdeger $^{10}, \operatorname{Sartr}^{11}$, Jaspers $^{12}$ ), a kasnije i lingvista koji su je posmatrali na materijalu više različitih

9 Delo u kojem se Aristotel najviše bavi ontološkom tematikom je „Metafizika“, gde je predstavio svoje viđenje bića i bivstvovanja. Ovo delo koje danas pronalazimo u brojnim izdanjima u celom svetu prvobitno je bilo sastavljeno od 14 traktata koje je preuredio Andronik iz Rodija tri veka nakon smrti čuvenog filozofa..

10 Martin Hajdeger, jedan od značajnijih predstavnika egzistencijalizma u filozofiji, izložio je temelje svoje filozofije u delu „Bitak i vreme“ (M. Heidegger, Sein und Zeit, Halle, Max Niemeyer, 1927).

11 Žan Pol Sartr, tvorac ateističkog egzistencijalizma, predstavio je osnove svoje filozofije u delu „Egzistencijalizam je humanizam“, ( J.P. Sartre, L'existentialisme est un humanisme, Paris, Édition Nagel, 1946).

12 Karl Jaspers, predstavnik hrišćanskog egzistencijalizma izložio je svoje najvažnije egzistencijalističke ideje u dva ključna dela - „Filozofija egzistencije“ (K. Jaspers, Existenzphilosophie, Drei Vorlesungen, Berlin, De Gruyter, 1938) i „Um i egzistencija“ (K. Jaspers, Vernunft und Existenz, Groningen, Wolters, 1935). 
jezika (Jesperson, Bondarko, Kiklič, Referovskaja, Luht, itd.) (Lazić-Konjik 2009: 360-361). Kategorija egzistencije je veoma složena semantička kategorija koja obuhvata različite načine postojanja, od konkretnog u određenom vremenu i prostoru do apstraktnog i imaginarnog, koje svoju realizaciju ostvaruje u mentalnoj sferi čovekovog uma. Sa ovom kategorijom je tesno povezana potpuno suprotna kategorija nepostojanja, koju ćemo takođe uključiti u naše istraživanje, u vidu negacije svega onoga što predstavlja postojanje, a što se lingvistički postiže negacijom egzistencijalističkih glagola. Osnovno značenje egzistencijalističkih glagola u srpskom jeziku je „biti, postojati“, dok su varijantna značenja ,prisustvovati“, „,nalaziti se“, „živeti““ itd. (Lazić-Konjik 2009: 363). Glagol koji je u italijanskom jeziku najbliži leksičkom centru funkcionalno-semantičkog polja egzistencije je esserci u trećim licima: c'è / ci sono (Cruschina 2012 : 79), te egzistencijalno značenje možemo posmatrati u sintaksičkim strukturama sa ovim glagolom.

Iako se i u egzistencijalnim rečenicama pod određenim uslovima može pojaviti nulta imenička sintagma (Blatešić 2012: 71-78), za temu ovog rada bitniji je opis uslova za pojavljivanje nultog člana u elipsi ili takozvanim nominativnim rečenicama, u kojima dolazi do izostavljanja predikata. Stoga ćemo u ovom odeljku prikazati pojavu SNØ u elipsama, koje su u dubinskoj strukturi egzistencijalne rečenice. Tako smo u primerima iz korpusa zapazili da izostavljanje glagola, inače prisutnog u dubinskoj strukturi, dovodi do još nekih promena na površinskoj strukturi rečenice, koje se ne tiču samo izostavljanja člana kao determinante SN, već i distribucije rečeničnih konstituenata. U primerima (38) i (39) prikazali smo više potencijalnih ostvarenja istih rečenica, gramatička i negramatička (obeležena asteriskom) i pri tome ustanovili nekoliko identičnih pojava.

Kao što se vidi u primerima (38a, 39a), SN u inicijalnom položaju u egzistencijalnoj rečenici sa izraženim glagolom esserci mora da ima determinantu, jer je u suprotnom rečenica negramatična, što nam pokazuju primeri $(38 b, 39 b)$ i (38c, 39c). Imenička sintagma sa determinantom je neophodna u preverbalnom položaju, kao u primerima (38f, 39f), gde SD ima veoma naglašen, tj. markiran položaj zbog postavljanja odredbe za mesto i vreme na inicijalno mesto. SN u postverbalnom položaju može da sadrži determinantu (38d, 39d), ali je dozvoljena i pojava SNØ i SN sa partitivnim članom, kao u primerima (38e, 39e). Zaključujemo da na pojavu SNØ u iskazima utiče izostavljanje glagola esserci, ali i postverbalni položaj imeničke sintagme.

(38) Nidi tra i rami. (QS, str. 74)

a) I nidi ci sono tra i rami.

b) *ØNidi ci sono tra i rami.

c) *Dei nidi ci sono tra i rami.

d) Tra i rami ci sono $i$ nidi.

e) Tra i rami ci sono Ønidi / dei nidi.

f) Tra i rami $i$ nidi ci sono. 
(39) Rumori nella notte. (QS, str. 74)

a) I rumori ci sono nella notte.

b) *ØRumori ci sono nella notte.

c) *Dei rumori ci sono nella notte.

d) Nella notte ci sono i rumori.

e) Nella notte ci sono Ørumori / dei rumori.

f) Nella notte $i$ rumori ci sono.

\subsection{Negacija u strukturi 'niente $+\mathrm{SN} \varnothing$ '}

U egzistencijalnim rečenicama sa negacijom može da se izostavi glagol, pri čemu iskaz preuzima oblik strukture sa prilogom niente i nultom imeničkom sintagmom ,niente + SNØ”. Negacija podrazumeva negiranje postojanja neke pojave ili predmeta, što dovodi u pitanje upotrebu determinanti, jer u takvom kontekstu imenice lako gube referencijalnost. Stoga član i u egzistencijalnim rečenicama sa negacijom može da izostane pod određenim uslovima, uglavnom u postverbalnom položaju $(40,41)$, dok se u eliptičnoj strukturi sa prilogom niente imenička sintagma redovno pojavljuje bez člana (42).

(40) a) Non c'è problema. $\rightarrow$ b) Il problema non c'è.

(41) a) Non c'è dubbio. $\rightarrow$ b) Il dubbio non c'è.

(42) Niente soldi. $\rightarrow$ I soldi non ci sono.

Prilog niente već sadrži u sebi značenje non c'è, koje srećemo u egzistencijalnim rečenicama sa negacijom, ali za razliku od egzistencijalnog glagola u negaciji non esserci, uz koji mogu da se koriste i nulte i determinisane imeničke sintagme, niente zahteva upotrebu SNØ, jer semantika ovog priloga u potpunosti negira pojam na koji se odnosi. Naravno, iza niente se mogu naći SNØ u oba broja: u jednini $(43,44)$ i u množini $(45,46)$ :

$$
\text { ,niente + SNØ (Sg.)“ }
$$

(43) Niente rivoluzione. (QS, str. 117)

(44) Niente cibo e molto lavoro, mi disse. (QS, str. 129)

$$
\text { „niente + SNØ (Pl.)“ }
$$

(45) Niente curve. (NHP, str. 6)

(46) Niente pianti e urli. (NHP, str. 68)

Distribucija priloga i imeničke sintagme je veoma važan faktor u opisanoj strukturi, jer se $u$ isključivo postadverbijalnom položaju negira pojam na koji se odnosi SNØ. S druge strane, ukoliko je imenička sintagma preadverbijalna, prilog niente dobija značenje koje zavisi od sintaksičko-semantičkog konteksta. Tako se ovaj prilog u primeru (47) odnosi na glagol vedere iz prethodne rečenice, te ovako 
upotrebljeno niente ne treba mešati sa strukturom „niente + SNØ“e, koja uvek ima značenje negacije egzistencijalnosti pojma na koji se odnosi imenička sintagma.

(47) Poi lo videro anche gli altri due. Gente intorno, niente. (QS, str. 73)

$\rightarrow$ La gente intorno non lo vide.

\section{ZAKLJUČAK}

Nulta imenička sintagma (SNØ), koja je osnovni predmet istraživanja ovog rada, veoma je frekventna u eliptičnim strukturama, tj. u iskazima sa izostavljenim glagolom. S obzirom na to da su takve strukture slične ili čak identične na površinskom nivou, rekonstruisali smo njihovu dubinsku strukturu kako bismo stekli potpuniji uvid u uslove koji dovode do izostavljanja člana u imenici. Rezultate istraživanja iznosimo na osnovu uvida u korpus koji smo predstavili u prvom odeljku ovog rada. Za ovo istraživanje bilo je važno uzeti u obzir vrstu glagola koji se izostavlja u elipsi, kao i najuži sintaksičko-semantički kontekst u kojem je upotrebljena elipsa.

Tako smo već u elipsama sa izostavljenim predikatom punog značenja uočili da se nulta imenička sintagma veoma retko javlja u subjekatskoj funkciji, uglavnom u slučajevima elipse ,in praesentia“ u okviru teksta. Najčešća upotreba SNØ je ipak u funkciji objekta u množini ili u jednini ako je reč o zbirnim i gradivnim imenicama, a karakteristična je kako za elipse ,in praesentia“ tako i za elipse ,,in absentia“. Istraživanje iz pregledanog korpusa pokazalo je da su nulte imeničke sintagme u množini u funkciji objekta češća pojava u eliptičnim strukturama italijanskog jezika, dok razloge za ipak ređu upotrebu SNØ u jednini u funkciji objekta, pronalazimo u uticajima starog jezika. Naime, nakon napuštanja sistema fleksije latinskog jezika formiranje današnjeg oblika člana, kao i njegova upotreba u jasno definisanoj strukturi trajalo je vekovima, na šta su već ukazali mnogi italijanski lingvisti (Bembo 1525: 91-92, Gigli 1729: 42, Zamboni 2003: 197-198). Upotreba SNØ u starom italijanskom jeziku nije bila povezana sa namernim napuštanjem sistema determinacije, već je, kako ističu navedeni autori, bila posledica prelaska sa latinskih imenica koje nisu imale kategoriju člana. Ostatke ove tranzicije pronalazimo u strukturama koje čuvaju odlike arhaičnog jezika, a to su upravo ustaljeni izrazi, kolokacije i poslovice. Tako ni strukture sa objekatskom SNØ u jednini nisu neobične u savremenom jeziku, jer su nastale po modelu davno kristalizovanih izraza u jeziku, a veoma su frekventne one koje sadrže apstraktnu imenicu (avere pazienza), one koje zbog učestale upotrebe nemaju potrebu za isticanjem referenta (fare lezione) i one koje se mogu parafrazirati (menzionare - fare menzione).

Što se tiče rečenica sa izostavljenim kopulativnim glagolom pojava nultog člana veoma je česta, jer brisanje glagola essere utiče na gubljenje determinante imeničke sintagme, što je izraženo u poslovicama sa tipološki različitim imeničkim sintagmama, ali i u elipsama slobodnih struktura. U površinskoj strukturi ovakvih elipsi 
SNØ zauzimaju inicijalni položaj, dok tek u dubinskoj strukturi zapažamo da te SN imaju različitu distribuciju (postkopulativnu i prekopulativnu) i različitu funkciju (funkciju subjekta i nominalnog dela predikata). SN koje imaju funkciju subjekta su determinisane u dubinskoj strukturi, ali u površinskoj gube član. SN koje imaju funkciju nominalnog dela predikata i u dubinskoj strukturi sadrže nulti član, jer je za pojavu SNØ veoma pogodan i čak uobičajen postkopulativni položaj. Tako je pojava SNØ u sličnim primerima na površinskom nivou Risposta esatta (17) i Questione di un attimo (29) rezultat potpuno drugačijih uslova. Pridev u postnominalnom položaju u eliptičnoj strukturi može biti deo predikata ili nosilac drugih sintaksičkih odnosa, ali svakako ne utiče na pojavu člana. Prenominalna upotreba prideva ukazuje na drugačiju dubinsku strukturu, sa članom, koji se u površinskoj strukturi briše zbog funkcionalne ekonomije jezika. Samo izostavljanje glagola, tj. pojava elipse ipak nije dovoljan uslov za upotrebu SNO, što nam pokazuje primer iskaza sa izostavljenim semikopulativnim glagolom (37).

U elipsama koje su rezultat izostavljanja egzistencijalnog glagola samo postverbalni položaj omogućuje pojavu SNØ. Negacija se pokazala kao veoma važan faktor za izostavljanje determinante, jer već samo negiranje neke pojave ukazuje na nedostatak referencije. Negacija postignuta uz pomoć priloga niente ne dozvoljava pojavu člana u SN u desnoj lokaciji, tako da je za ovu vrstu negacije karakteristična upravo SNØ.

\section{LITERATURA}

Bagić, K. (2010). Dva lica patosa. Vijenac: novine Matice hrvatske za književnost, umjetnost i znanost, 427-429, preuzeto 30. aprila 2014. sa http://www.matica.hr/vijenac/427/Dva\%20 lica\%20patosa/

Bembo, P. (1525). Prose della volgar lingua. Venezia: Giovanni Tacuino.

Benincà, P. (1980). Nomi senza articolo. In: Antinucci, F., Cinque, G. (eds.) (1980). Rivista di Grammatica Generativa, Vol. 5, (pp. 51-63). Padova: CLESP Editrice.

Blatešić, A. (2012). Nulti član u savremenom italijanskom jeziku. Doktorska teza. Beograd: Filološki fakultet.

Cardinaletti, A. (2009). Esercizi di sintassi. Roma: Carocci.

Casalegno, P. (1987). Sulla logica dei plurali. Teoria, 2, 125-143.

Contreras, H. (1986). Spanish bare NPs (Noun Phrases) and the ECP (Empty Category Principle). In: I. Bordelois, $\mathrm{H}$.

Contreras \& K. Zagona (eds.) (1986). Generative Studies in Spanish Syntax (pp. 25-49). Dordrecht: Foris.

Corno, D. (2010). Ellissi. Enciclopedia dell'italiano. Preuzeto 10. maja 2014. sa http://www. treccani.it/enciclopedia/ellissi_(Enciclopedia_dell'Italiano)

Cresti, E., Moneglia M. (eds.) (2005). C-ORAL-ROM Italian Integrated Reference Corpora for Spoken Romance Languages. Amsterdam: Benjamins.

Cresti, E. (1998). Gli enunciati nominali. In: Navarro Salazar, M.T., Cesati F. (eds.) (1998). Italica Matritensia. Atti del IV convegno della Società Internazionale di Linguistica e Filologia Italiana, 171-191. Madrid: Universidad nacional de educación a distancia. 
Cruschina, S. (2012). Focus in Existential Sentences. In: Bianchi, V., Chesi, C. (eds.) (2012). Enjoy Linguistics! Papers offered to Luigi Rizzi on the occasion of his 60th birthday (pp. 77-107). Siena: CISCL Press.

Dayal, V. (2004). Number Marking and (In)definiteness in kind terms. In: Zimermann, Th. E., Forbes G. (eds.) (2004). Linguistics and Philosophy, Vol. 27, No. 4, (pp. 393-450). Dordecht: Kluwer Academic Publishers.

Giglio, G. (1729). Lezioni di lingua toscana. Venezia: Bartolomeo Giavaro.

Korzen, I. (1996). L'articolo italiano fra concetto ed entità. Copenhagen: Museum Tusculanum Press.

Kristal, D. (1998). Enciklopedijski rečnik moderne lingvistike (2. izd.). Beograd: Nolit.

Lazić-Konjik, I. (2009). O funkcionalno-semantičkoj kategoriji egzistencije u srpskom jeziku. Južnoslovenski filolog 01/2009, LXV, (str. 359-374). Beograd: Srpska akademija nauka i umetnosti: Institut za srpski jezik SANU.

Longobardi, G. (1994). Reference to Kinds and proper names: a theory of N-movement in Syntax and Logical form. In: Keyser S.J. (ed.) (1994). Linguistic Inquiry, 25, (pp. 609-665). The Massachusetts Institute of Technology (MIT Press).

Fontanier, P. (1968). Les figures du discours. Paris: Flammarion.

Mancini, M. (2007). Scrittura del tumulto e tumulto della scrittura. Aspetti metanarrativi e metalinguistici in Promessi sposi XI-XVI. In: Zito P. (ed.) (2007). Italica, Winter, Vol. 84, No.4, (pp. 708-722). Bloomington: Indiana University Press.

Marini, E. (2003). Tipologia delle costruzioni a verbo supporto ad "articolo zero" in italiano antico e moderno. In: Poggi S. T., Maraschio, N. (eds.) (2003). Atti del XXXIV Congresso internazionale di studi della SLI "Italia linguistica anno Mille - Italia linguistica anno Duemila", (pp. 259-272). Roma: Bulzoni.

Pennacini, A. (ed.) (2001). Institutio oratoria, vol. 1-2. Torino: Einaudi.

Tateo, F. (1970). Ellissi. Enciclopedia dantesca, Vol.16. Preuzeto 24. maja. 2014. sa online izvora: http://www.treccani.it/enciclopedia/ellissi_Enciclopedia-Dantesca)

Zamboni, A. (2003). Alle origini dell'italiano. Dinamiche e tipologie della transizione dal latino. Roma: Carocci editore.

Zamparelli, R. (2002). Definite and bare kind-denoting bare nouns. In: Beyssade C., Bock-Bennema R., Drijkoningen, F.\& Monanchesi, P. (eds.) (2002). Romance Languages and Linguistics Theory 2000 (pp. 305-343). Amsterdam: John Benjamins.

Skraćenice korištene za književna dela iz korpusa:

GDM - Biagi, E. (2000). Giro del mondo, Milano: Rizzoli.

NDR - Eco, U. (2007). Il nome della rosa. Milano: Tascabili Bompiani.

NHP - Ammaniti, N. (2001). Non ho paura. Torino: Giulio Einaudi Editore.

QS - Baricco, A. (2007). Questa storia. Milano: Feltrinelli.

SIP - Cecovini M. (1995), Straniero in paradiso. Trieste: MGS Press Editrice 
Aleksandra Blatešić

\title{
BARE NOUN PHRASES IN ELLIPTICAL STRUCTURES OF THE ITALIAN LANGUAGE
}

\begin{abstract}
SUMMARY
The basic theme of this paper are bare noun phrases, which in the Italian language often appear in reduced syntactic structures. Omitting redundant syntactic units is caused by several reasons, among which the most important are economy of language, emphasis and style. The occurrence of bare noun phrases in Italian often coincides with ellipsis, so we have paid special attention to the type of ellipsis (rhetorical and grammatical) where bare nouns appear, and to the types of verbs which is omitted in elliptical structure (verbal predicates, copulative verbs, semi-copulative verbs, existential verbs). We have analysed these reduced statements at the levels of surface as well as deep structures of sentences, relying on the principles of generative grammar and on modern structural methods. The survey results represent syntactic and semantic conditions as well as linguistic contexts, that cause SNØ in ellipsis. ellipsis

Keywords: Italian language, noun phrases, omitting articles, grammatical ellipsis, rhetorical
\end{abstract}

